๑ e ISSN-0976-6855 | Visit us : www.researchjournal.co.in

\title{
Dissipation and decontamination of imidacloprid and lambda - cyhalothrin residues in brinjal
}

\author{
S.P. GUPTA*, S.P. SINGH, PAIDI SATYANARAYANA AND NAGENDRA KUMAR \\ Department of Entomology, Rajendra Agricultural University, Pusa, SAMASTIPUR (BIHAR) INDIA
}

\section{ARITCLE INFO}

Received : 18.04 .2015

Revised : 15.09 .2015

Accepted : 28.09 .2015

\section{KEY WORDS :}

Dissipation, Decontamination, Imidacloprid, Lambda - cyhalothrin, Brinjal

*Corresponding author: Email: surya22gupta@gmail.com

\begin{abstract}
Residues ofimidacloprid at $20 \mathrm{~g}$ a.i. $\mathrm{ha}^{-1}$ and lambda - cyhalothrin at $15 \mathrm{~g}$ a.i. ha ${ }^{-1}$ were estimated quantitatively by HPLC/GLC in/on brinjal fruits. Initial deposits of insecticides were higher in imidacloprid than lambda - cyhalothrin. Initial deposits of $0.652 \mathrm{mg} \mathrm{kg} \mathrm{kg}^{-1}$ of imidacloprid dissipated to 93.17 per cent on $10^{\text {th }}$ day. In lambda - cyhalothrin the initial deposits were $0.138 \mathrm{mg} \mathrm{kg}^{-1}$ which dissipated to 92.75 per cent on $10^{\text {th }}$ day. The degradation of imidacloprid was relatively higher as compared to lambda - cyhalothrin. Both imidacloprid and lambda - cyhalothrin had half - life values of 1.92 and 2.65 days, respectively on brinjal fruits. The safe waiting period for imidacloprid was found 4.70 days. In lambda - cyhalothrin, no waiting period is required after its application as the initial deposits were less than its MRL $\left(0.3 \mathrm{mg} \mathrm{kg}^{-1}\right)$.
\end{abstract}

How to view point the article : Gupta, S.P., Singh, S.P., Satyanarayana, Paidi and Kumar, Nagendra (2015). Dissipation and decontamination of imidacloprid and lambda - cyhalothrin residues in brinjal. Internat. J. Plant Protec., 8(2) : 379-383. 